\title{
透析量および栄養状態などを表す指標のグラフ化
}

\author{
加 藤 謙 吉 浅 野 泰* \\ 加藤クリニック 自治医科大学腎臟内科*
}

\begin{abstract}
key words : 慢性透析患者, 透析量評価, 栄養評価, 透析評価グラフ, インフォームド・コンセント
〈要旨〉

これまで報告されてきた慢性透析患者の治療の指標である $\mathrm{Kt} / \mathrm{V}$ や計算によって得られたエネルギー摂取量など をもとに透析デー夕評価表を月次ごとに作製してきた. 観察期間は 1 年 6 か月で, 症例数 46 53 人, 平均透析期間 $55.8 \pm 44.1 \sim 67.1 \pm 43.8$ か月 (最小〜最大值, mean $\pm \mathrm{SD}$ ), $\mathrm{TAC}_{\mathrm{BUN}} 43.5 \pm 9.6 \sim 48.6 \pm 11.5 \mathrm{mg} / \mathrm{d} l, \mathrm{Kt} / \mathrm{V} 1.22 \pm$ $0.19 \sim 1.34 \pm 0.27$, PCR $0.96 \pm 0.21 \sim 1.07 \pm 0.15 \mathrm{~g} / \mathrm{kg} /$ day, アルブミン值 $4.0 \pm 0.3 \sim 4.3 \pm 0.4 \mathrm{~g} / \mathrm{d} l$, エネル

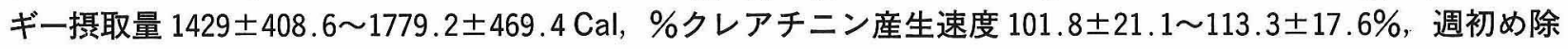

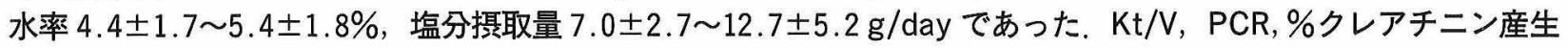
速度については日本透析医学会統計調査委員会の算出結果とも比較を行い有意な相関が認められた（ $r=0.65 \sim$ 0.99).ささらにこれら評価表をもとに個別的に折れ線グラフまたはレーダーグラフを作製した. グラフ化は数值羅列 の表形式よりも臨床全体像をとらえやすく, 透析スタッフや患者に対し, 病態や食事管理への理解がより深まる結 果となった，すなわち, 透析評価表のグラフ化は透析患者に対するインフォームド・コンセントとしての役割を十 分担えるものと考えられる.
\end{abstract}

\section{Graphic representation of quantitative indices for hemodialysis and nutritional state}

Kenkichi Kato, Yasushi Asano*

Kato Clinic ; Department of Nephrology in Jichi Medical School*

Hemodialysis data obtained from 46 to 53 chronical hemodialysis patients at our clinic, including $\mathrm{Kt} / \mathrm{V}$ and energy intake, were analyzed every month for 18 months. Statistical analysis demonstrated a mean hemodialysis duration of $55.8 \pm 44.1$ to $67.1 \pm 43.8$ months (minimum to maximum in mean $\pm S D$ ), a $T_{A C} C_{\text {BuN }}$ value of $43.5 \pm 9.6$ to $48.6 \pm 11.5 \mathrm{mg} / \mathrm{d} l$, a Kt/V value of $1.22 \pm 0.19$ to $1.34 \pm 0.27$, a PCR value of $0.96 \pm 0.21$ to $1.07 \pm 0.15 \mathrm{~g} / \mathrm{kg} /$ day, an albumin value of $4.0 \pm 0.3$ to $4.3 \pm 0.4 \mathrm{~g} / \mathrm{d} l$, an energy intake of $1429 \pm 408.6$ to $1779.2 \pm 469.4 \mathrm{Cal}$, a $\%$ creatinine production rate of $101.8 \pm 21.1$ to $113.3 \pm 17.6 \%$, a weekly initial water removal rate of $4.4 \pm 1.7$ to $5.4 \pm 1.8 \%$, and a salt intake of $7.0 \pm 2.7$ to $12.7 \pm 5.2 \mathrm{~g} /$ day. Regarding the $\mathrm{Kt} / \mathrm{V}$, $\mathrm{PCR}$, and \% creatinine production rate, a significant correlation was found ( $r=0.65$ to 0.99$)$, in comparison with respective calculations by the Statistical Survey Committee of the Japanese Society for Dialysis Therapy. Based on these assessment tables, respective lines or radar graphs were drawn. This graphic representation demonstrated the overall clinical information more clearly than tabular numerical representation, and improved the understanding of hemodialysis staff and patients regarding the pathologic state and dietary management. We concluded that graphic representation of hemodialysis assessment data is useful to obtain informed consent from hemodialysis patients.

加藤 謙吉 加藤クリニック％ 323-0807 栃木県小山市城東 6-6-7 (0285-21-1133)

Kenkichi Kato Fax 0285-21-1134

〔受付: 平成 10 年 10 月 5 日, 受理 : 平成 10 年 12 月 29 日〕 


\section{緒 言}

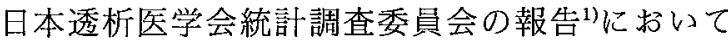
も，予後に関連する指標が多数検討されている。また， それとは別に慢性透析患者の食事摂取量（中でもエネ ルギー摂取量）などを定量的に算出しようとする試み が報告されている2).すなわち，個々の症例の透析量や 栄養状態, 血圧などの循環器系の諸因子, さらには種々 の合併症にかかわる諸因子などを適切に評価すること が，予後を推定する上で極めて重要だといえる，そこ で，個々の症例に対し，これらの指標を定期的に算出 すれば，その都度透析量や栄養状態などの評価が可能 となるはずである。しかしさらに一歩進み，その指標 を患者の指導にまで応用しようと考えた場合，患者に とっては難解な面も多々あると思われる。これまでの 長期透析患者への指導は，例えば採血デー夕の結果を 知らせ，その值の高低值で改善を促すような指導形態 をとっている場合が多かった．今後は適切な指標を有 効に活用し，功患者には難解な内容でも，わかり易 く説明し治療効率を向上させる心゙きかと考える，そこ で今回の検討を行った。

\section{I 、対象および方法}

\section{1. 透析デー夕評価表}

1 ) 対象症例

1997 年 1 月から 1998 年 6 月までの期間に当院で治 療を行った週 3 回透析症例を対象とした。無尿である
ことを原則としたが,一部無尿でない症例も含まれた。 その無尿でない症例についての評価はあくまでも参考 程度とした。

2 ）個別的な透析デー夕評価表の作製

以下のような指標をもとに月次ごとに各症例の透析 デー夕評価表を作製した。なお，作製にあたり利用し た計算式を表 1 に提示する。

(1) $\mathrm{TAC}_{\mathrm{BUN}}$ (time averaged concentration of BUN ; 尿素窒素平均值) $[\mathrm{mg} / \mathrm{d} l]$ (2) Kt/V (標準化透 析量) [無単位] (3) PCR (protein catabolic rate $\fallingdotseq$ 蛋 白摄取量) $[\mathrm{g} / \mathrm{kg} / \mathrm{day}]$ (4) 1 日摂取エネルギー量（カロ

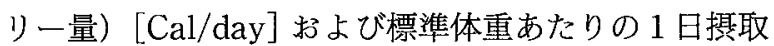
エネルギー量 $[\mathrm{Cal} / \mathrm{kg} / \mathrm{day}]$ (5) \%クレアチニン産生速 度（筋肉量） [\%] (6) 週初め除水率 (体重増加率) [\%] (7) 食塩捸取量 $[\mathrm{g} / \mathrm{day}]$ (8) 透析前アルブミン值 $[\mathrm{g} / \mathrm{d} l]$ である:なお，患者に説明するときに用いた用語を（） 内に示した。 また，[ ]内は単位である。これらのデー 夕は，市販データベースソフトである FileMakerPro, Ver 4.0（FileMaker 社製）を利用し表形式で表示し た。各指標における計算式に関してはそれぞれの フィールド定義内に計算式を入れ，必要なデー夕を入 力すれば自動的にそれぞれの指標の結果が出るように なっている.手入力を必要とした項目は, (1) 検査年月, (2) 氏名 [カ夕カナ], (3) 性別, (4) 年龄, (5) 透析回数, (6) 透析時間 [分], (7) 透析間時間 [時間], (8) 週初め透 析前体重および (9) 後体重 $[\mathrm{kg}]$, (10) 週 2 回目の透析前 体重 $[\mathrm{kg}]$ ，(11) 週初め透析前尿素窒素および (12) 後尿素 窒素 $[\mathrm{mg} / \mathrm{d} l]$, (13) 週 2 回目の透析前尿素窒素 $[\mathrm{mg} /$ $\mathrm{d} l]$, (14) 週初め透析前血清クレアチニンおよび (15) 後血

表 1 当院で利用している計算式

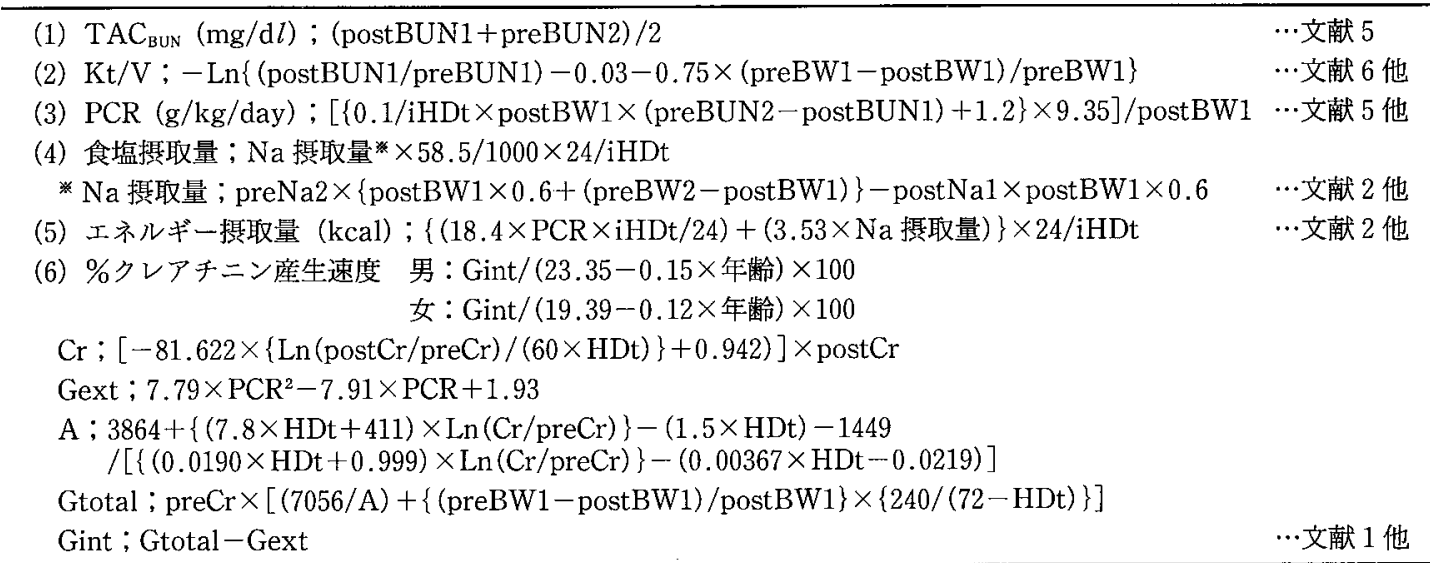

○週初めの透析前尿素窒素； preBUN1 ○週初めの透析後尿素窒素； postBUN1

○週 2 回めの透析前尿素窒素; preBUN2

○週初內の透析前体重; preBW1 ○週初めの透析後体重；postBW1

○週初め透析後から週 2 回め透析までの時間 ; iHDt ○現在の透析時間 ; HDt

○週初めの透析後ナトリウム； postNa1 O週 2 回めの透析前ナトリウム； preNa2

○週初めの透析前クレアチニン; preCr ○週初めの透析後クレアチニン； postCr 
表 2 当院計算値と簡便式および統計調査委員会送付ソフト算出値と の比較（1998 年 6 月）

\begin{tabular}{|c|c|c|c|}
\hline & $\mathrm{Kt} / \mathrm{V}$ & $\begin{array}{c}\text { PCR } \\
(\mathrm{g} / \mathrm{kg} / \text { day })\end{array}$ & $\begin{array}{c}\% \text { \%ノアニン産生速度 } \\
(\%)\end{array}$ \\
\hline a. 当院計算值平均 & $1.27 \pm 0.17$ & $1.06 \pm 0.20$ & $107.8 \pm 19.5$ \\
\hline b. 簡便式（新里） & $1.30 \pm 0.16$ & $0.98 \pm 0.15$ & $113.2 \pm 17.8$ \\
\hline $\begin{array}{l}\text { C . 統計調查委員会 } \\
\text { 送付ソフト使用 }\end{array}$ & $1.29 \pm 0.16$ & $0.98 \pm 0.15$ & $105.0 \pm 16.6$ \\
\hline $\mathrm{a}$ と b との相関分析 & $\begin{array}{c}r=0.992 \\
\mathrm{p}<0.0001\end{array}$ & $\begin{array}{c}r=0.654 \\
p<0.0001\end{array}$ & $\begin{array}{c}r=0.867 \\
p<0.0001\end{array}$ \\
\hline b と c との相関分析 & $\begin{array}{c}r=0.999 \\
p<0.0001\end{array}$ & $\begin{array}{c}r=1.000 \\
\mathrm{p}<0.0001\end{array}$ & $\begin{array}{c}r=0.958 \\
p<0.0001\end{array}$ \\
\hline a と c との相関分析 & $\begin{array}{c}r=0.996 \\
p<0.0001\end{array}$ & $\begin{array}{c}r=0.652 \\
p<0.0001\end{array}$ & $\begin{array}{c}r=0.827 \\
p<0.0001\end{array}$ \\
\hline
\end{tabular}

清クレアチニン $[\mathrm{mg} / \mathrm{d} l]$, (16) 週初め透析後ナトリウム $[\mathrm{mg} / \mathrm{d} l]$, (17) 週 2 回目透析前ナトリウム $[\mathrm{mg} / \mathrm{d} l]$, (18) 週初めアルブミン值 $[\mathrm{g} / \mathrm{d} l]$ である。 なお，これらの データは初回入力時はすべて手入力が必要であった が，次回入力時には各デー夕の複製を行い，更新デー 夕箇所の消去とデー夕の再入力を行った，入力の際に は基礎となる検査データ（検査センターからパソコン 通信を利用し送られてきたPCデータをフロッピー ディスクで抜き出し Macintosh デー夕に変換したも の）を予め入力しやすい順番に並べ換えておいて利用 した.

また，一部の指標 $(\mathrm{Kt} / \mathrm{V}, \mathrm{PCR}, \%$ \%アチニン産 生速度）については，日本透析医学会統計調査委員会 より送付されたソフトおよび簡便法浪によってデー夕 を算出, 当院データとの比較を行った。

\section{2. 透析・自己管理評価グラフ}

透析デー夕評価表から得られたデー夕および週初め 透析前収縮期血圧 $[\mathrm{mmHg}]$, 週初め透析前心胸比 [\%] などの臨床デー夕を付け加えグラフ化をはかった，グ ラフは主にレーダーグラフを利用し，月次ごとの評価 を適宜行った．また，経時的な变化を表す際には折れ 線グラフも適宜利用した。

さらに同一グラフ内に当院月次平均值および患者ご との目標值をプロットし，比較の対照とした，グラフ 作製にあたり使用した市販ソフトは，DeltaGraphPRO Ver 3.5（Polaroid 社製）である.

\section{II. 結 果}

\section{1. 透析デー夕評価表}

1997 年 1 月から行ってきた当院での透析デー夕評 価表に扔ける月次平均值（最小值～最大值； mean \pm SD) は，症例数 46 53人，平均透析期間 $55.8 \pm$ $44.1 \sim 67.1 \pm 43.8$ 加月, $\mathrm{TAC}_{\text {BUN }} 43.5 \pm 9.6 \sim 48.6 \pm$ $11.5 \mathrm{mg} / \mathrm{d} l, \mathrm{Kt} / \mathrm{V} 1.22 \pm 0.19 \sim 1.34 \pm 0.27, \mathrm{PCR}$ $0.96 \pm 0.21 \sim 1.07 \pm 0.15 \mathrm{~g} / \mathrm{kg} / \mathrm{day} ， ア ル フ ゙ ミ ン$ 值 $4.0 \pm 0.3 \sim 4.3 \pm 0.4 \mathrm{~g} / \mathrm{d} l$ ，エネルギー攝取量 $1429 \pm$ 408.6 1779.2 $4469.4 \mathrm{Cal}$, \%クレアチニン産生速度 $101.8 \pm 21.1 \sim 113.3 \pm 17.6 \%$, 週初め除水率 $4.4 \pm$ $1.7 \sim 5.4 \pm 1.8 \%$ ，塩分摄取量 $7.0 \pm 3.7 \sim 12.7 \pm 5.2$ $\mathrm{g} /$ day であった。なお, 1998 年 6 月のデー夕に関して は透析医学会統計調査委員会送付ソフト执よび簡便法 での算出結果と当院データとの比較を行った（表 2 ）. また, 1998 年 6 月の各指標ごとにおける人数分布を観 察した (図 1 : 症例数 48 人)，そのうちの最大分布数に ついてのみ以下に記す. $\mathrm{TAC}_{\text {BUN }} 45.0 \sim 65.0 \mathrm{mg} / \mathrm{d} l$ 範 囲内が 27 人 $(56.3 \%), \mathrm{Kt} / \mathrm{V} 1.20$ 以上が 30 人 $(62.5$ $\%)$, PCR $0.80 \sim 1.40 \mathrm{~g} / \mathrm{kg} /$ day 範囲内が 41 人 (85.4\%),\%クレアチニン産生速度 110 以上が 25 人 $(52.1 \%)$, 血清アルブミン值 $3.5 \sim 4.5 \mathrm{~g} / \mathrm{d} l$ 範囲内 43 人 $(89.6 \%)$, 標準体重あたりのエネルギー摂取量 25 $\sim 35 \mathrm{Cal} / \mathrm{kg}$ 範囲内 24 人 $(50.0 \%)$, 週初为除水率 $2 \sim 6 \%$ 範囲内 35 人 $(72.9 \%)$, 食塩攝取量 $8 \mathrm{~g}$ 以上 34 人 (70.8\%) であった。さらに，参考までに 1998 年 3 月の当院における中 1 日の体重増加量と食塩摂取量と の関係についてみたところ（図 $2 a$ )，おおよそ中 1 日 

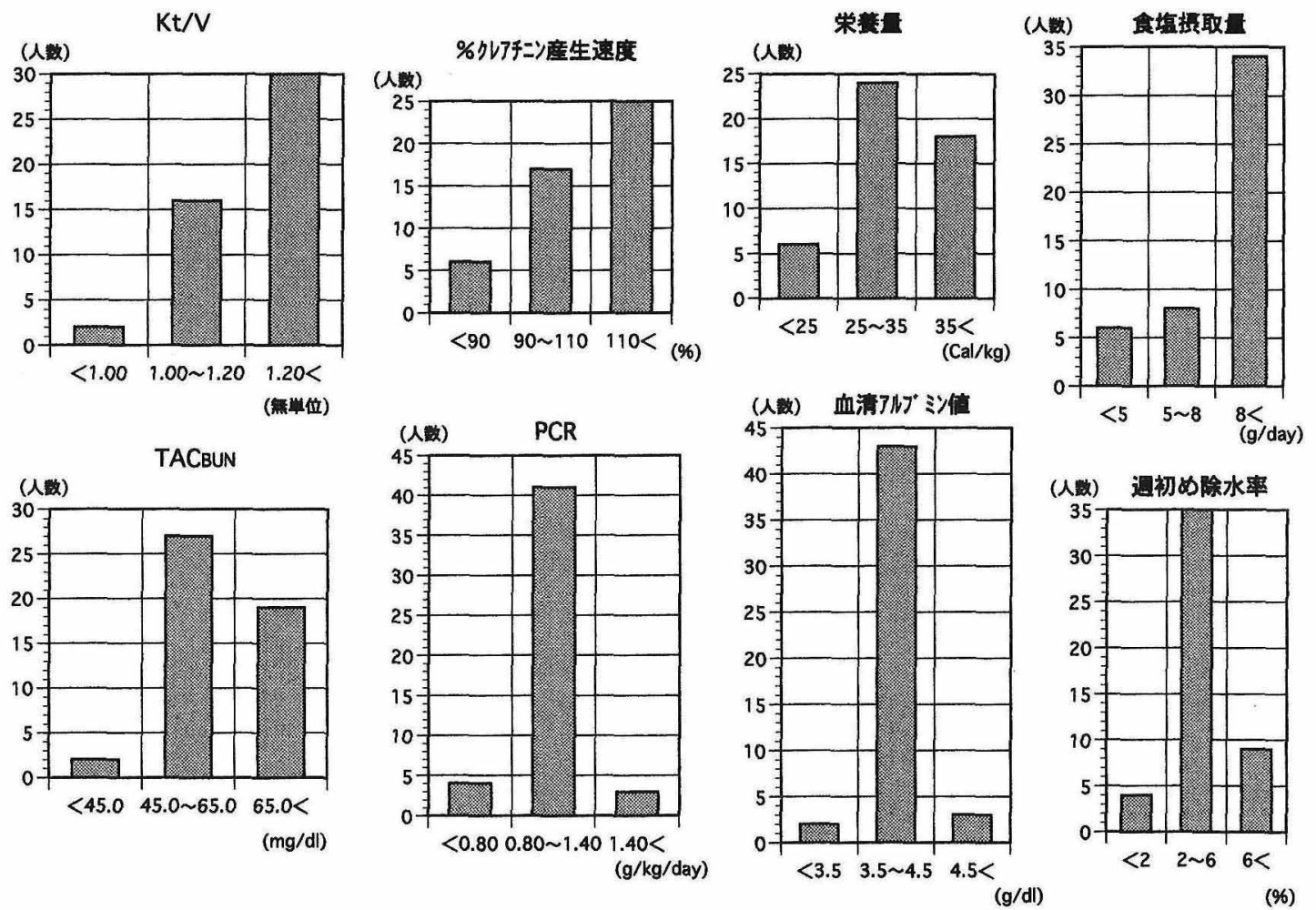

図 1 透析データ評価表における各指標ごとの当院患者分布 (対象症例数 48 人, 1998 年 6 月)

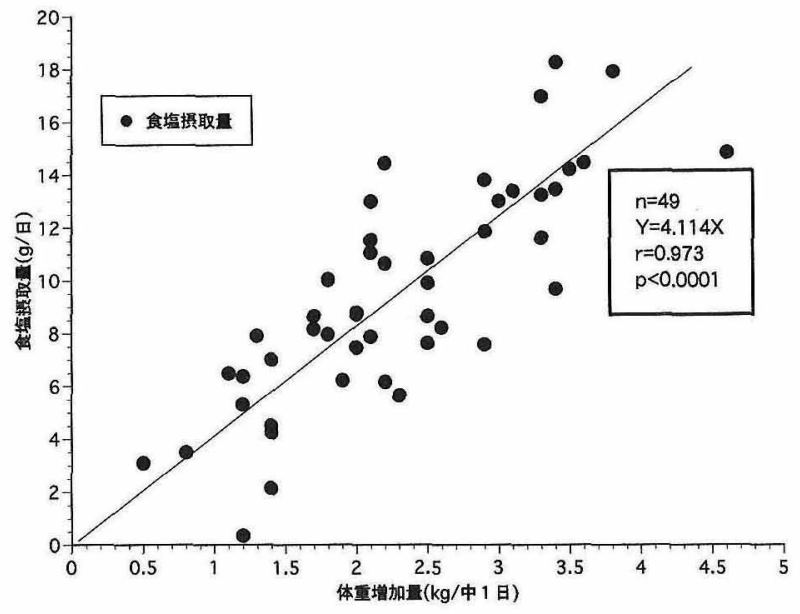

図 2 a 当院週 3 回透析例における体重増加量 と食塩摂取量との関係

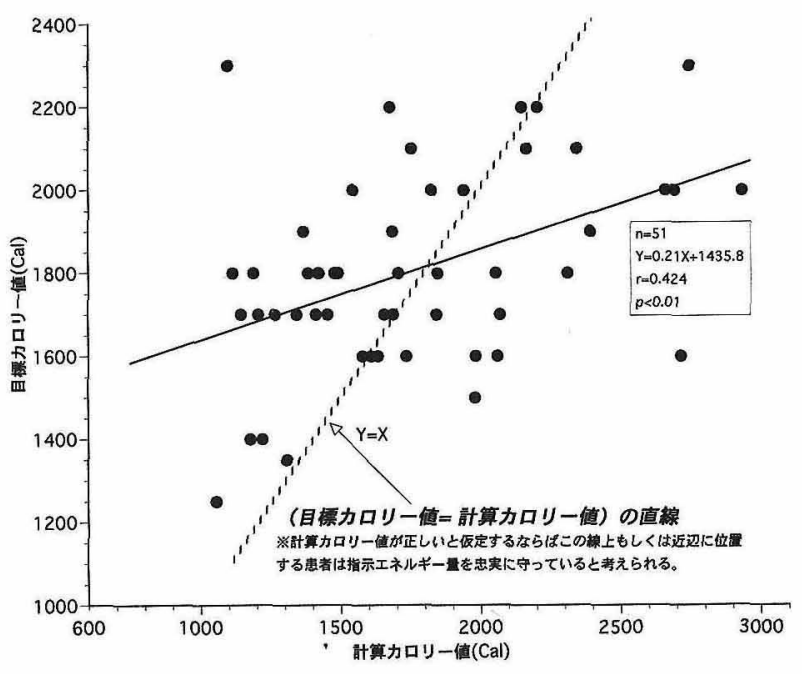

図 2 b 目標カロリー值と計算カロリー值との 関係
で体重 $1 \mathrm{~kg}$ 増加した場合， $4 \mathrm{~g}$ 程度の塩分を撖取して きていると考えられた(症例数 49 人, $\mathrm{Y}=4.114 \mathrm{X}, \mathrm{r}=$ 0.973, $\mathrm{p}<0.0001)$. また症例ごとに設定した目標カ口 リー值と計算カロリー值との間には $\mathrm{Y}=0.21 \mathrm{X}+$ $1435.8, \mathrm{r}=0.424, \mathrm{p}<0.01$ の関係が成り立った(図 2 b).

\section{2. 透析・自己管理評価グラフ}

まず当院の透析デー夕評価表から得られた月次平均 值（1998 年 6 月）を提示するとともに，レーダー図の
概ね意味する評価内容の枠組について図式化した（図 $3)$.

次に個々の症例を観察した中で, 特徴的であった具 体例を以下に呈示する。

(1) 症例 52 歳, 男性 ; 図 4 左下に示すように, この症例に対しては, $\mathrm{Kt} / \mathrm{V}$ および PCR の経時的変化 を折れ線グラフで呈示した，PCRについては原因不明 の関節痛と食事量減少との関連について言及し, 患者 の興味を注いだ。図 4 右上の月次レーダーグラフも参 
考にしてもらい，現在の透析量の不足を，当院透析例 の平均值や本人目標值と比較し視覚的に訴えた，さら にこの原因が血流量不足に起因していることを説明 し, 透析器膜面積の增大および透析時間の延長が必須 であることを説明した，その結果，これまで頑に時間 延長を拒否していたが，一部時間延長の同意が得られ た.

\section{(2) 症例 84 歳, 男性(図 5 ); 本症例は高齢で} ありながら家族，特に娘の厳格な食事管理のもとに生 活をしている．実行しているカロリー $1350 \mathrm{Cal}$ に対 し，計算で得られたものは $1309 \mathrm{Cal} て ゙$ 誤差 3.0\%，蛋 白質 $0.9 \mathrm{~g} / \mathrm{kg} /$ day $(45 \mathrm{~g} /$ day $)$ 実行値に対し, $0.91 \mathrm{~g} /$ $\mathrm{kg} /$ day $(48.4 \mathrm{~g} /$ day) で誤差 $7.6 \%$, 塩分は実行值 $6 \mathrm{~g} /$ day で計算值 $7.0 \mathrm{~g} /$ day, 誤差 $16.7 \%$ あった. 本症例

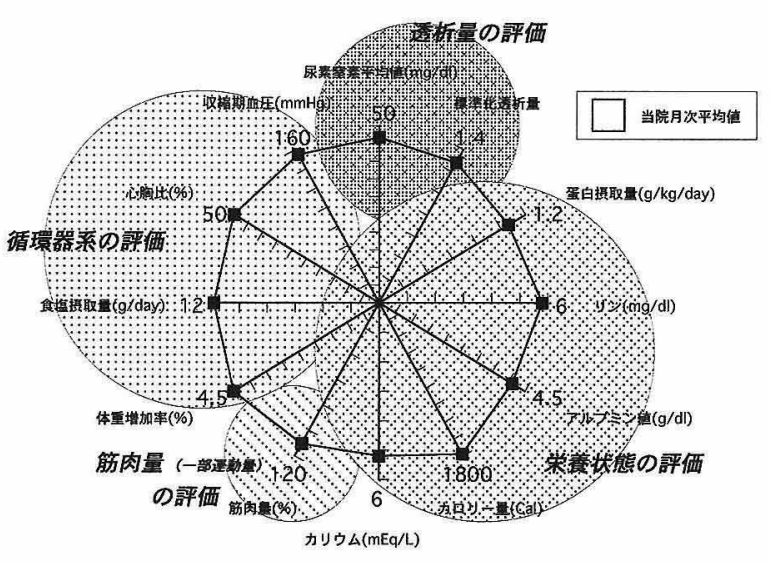

図 3 透析評価表月次平均値のレーダーグラフお よびその見方
を見る限り計算值にかなり信頼性がおける結果であっ た. 本症例の娘にこのグラフを呈示し, 現況での継続 的な食事管理を指導した.

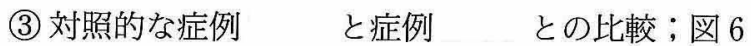

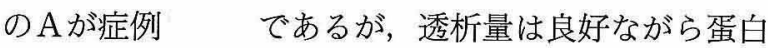
質, エネルギーともに少ないことが当院平均值および 目標值から伺える。もともとリンが高く，体重増加も 比較的多かったことから指導をくり返すうちに結局食 事量全体を抑制してしまったようである。そのため, 再指導により食事量全体の増量を促した. 図 6 の B (症 例）はその反対で食事量全体が多い.なるべく患 者が具体的目標を求められるように，全体的に 10〜20\%ぐらいの食事量の節制が必要であると指導し た。

(4)体重増加が極端に少ない症例場合（図 7 ）；無尿でありながら体重増加が極端に少ない場合, 食事攝取量が気になる。本症例の場合は $1 \%$ 程度の体 重増加だが，塩分摄取量および体重増加量を除く計算 值が目標值に達しているか，もしくは上回っている. 必要な食事攝取の中で厳格な塩分制限が行われてい た，本症例に対しては，その旨説明し現状維持を指導 した.

\section{III. 考 案}

米国から National Cooperative Dialysis Study と いう共同研究など4が発表され，透析における治療量

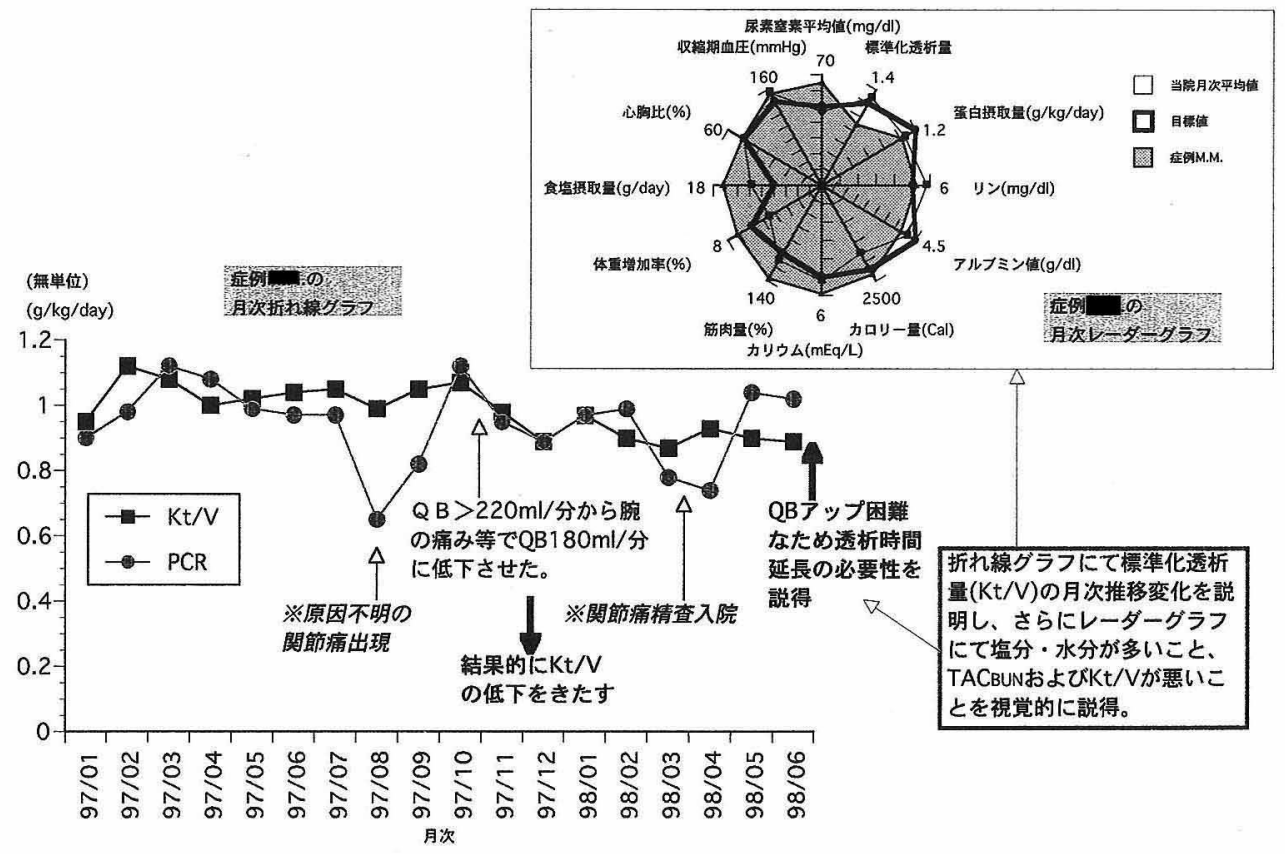

図 4 症例

(52 歳, 男性)における $\mathrm{Kt} / \mathrm{V}, \mathrm{PCR}$ の臨床的推移と月次レー ダーグラフ…その活用法 


\section{個別透析デー夕評価結果}

殿

透析自己管理評価表

\begin{tabular}{|c|c|c|c|}
\hline & 当月データ & 目標值 & $\begin{array}{l}\text { 当院当月 } \\
\text { 平均値 }\end{array}$ \\
\hline 尿素䇪素経時平均值 (mg/dl) & 38.5 & 65.0 以下 & 46.8 \\
\hline 標準化透析量 & 1.32 & $1.2 \sim \quad 1.60$ & 1.28 \\
\hline 蛋白摄取量 $(\mathrm{g} / \mathrm{kg} /$ 日) & 0.9 & $0.8 \sim \quad 1.2$ & 1.1 \\
\hline ソン $(\mathrm{mg} / \mathrm{dll})$ & 5.2 & $4.0 \sim \quad 6.0$ & 5.0 \\
\hline アルブミン $(\mathrm{g} / \mathrm{d} \|)$ & 3.5 & $4.0 \sim \quad 4.5$ & 4.1 \\
\hline カロリー量(Cal/日) & 1309 & 1350 & 1787 \\
\hline カリウム $(\mathrm{mEq} / \mathrm{L})$ & 4.3 & $3.5 \sim \quad 5.5$ & 4.3 \\
\hline 筋肉量(\%) & 137.3 & 100.0 以上 & 107.5 \\
\hline 体重増加率(\%) & 30 & $2.0 \sim \quad 6.0$ & 4.5 \\
\hline 食塩掑取量(g/日) & 7.0 & $3.0 \sim 8.0$ & 11.9 \\
\hline 心胸比 $(\%)$ & -54.4 & 50.0 以下 & 50.0 \\
\hline 収縮期血圧 (mmHg) & 109 & 140 以下 & 109 \\
\hline カルシウ $\Delta(\mathrm{mg} / \mathrm{dl})$ & 100 & $9.5 \sim \quad 10.5$ & 10.7 \\
\hline カルシウム・リン積 & 520 & 60 以下 & 53.4 \\
\hline
\end{tabular}

コメント：実施食事内容 : カロリー1350Cal, 蛋白 $0.9 \mathrm{~g} / \mathrm{kg} /$ day $(45 \mathrm{~g} / \mathrm{day})$ 塩分 $6 \mathrm{~g} /$ day

透析自己管理評価グラフ

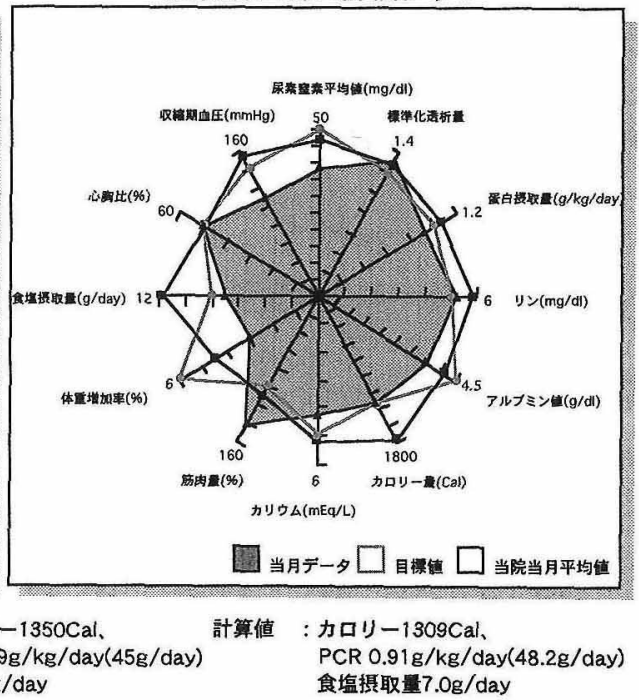

図 5 症例 (84 歳, 男性)。※家族（娘）による厳格な処方通りの食事管 理が計算值の信頼性を裏付けた.

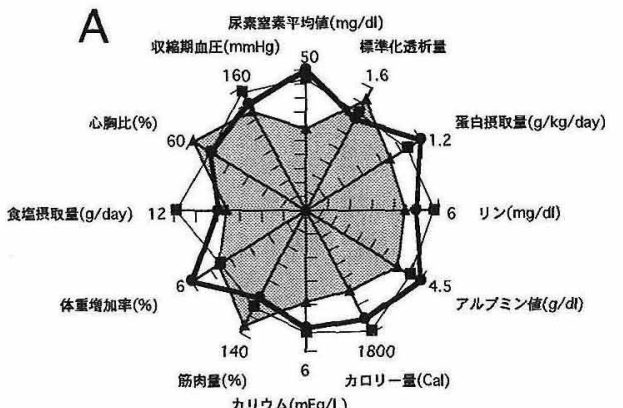

カリウム(MEG/L)

B

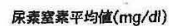

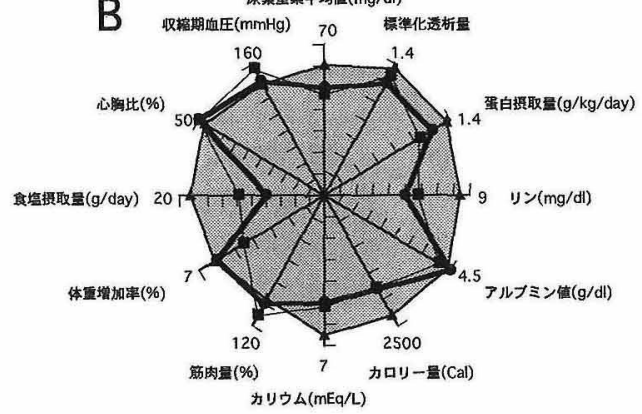

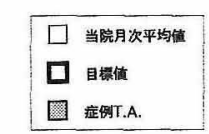

症例 61y.0.9 :

蛋白算、カロリーが不足。もと もとリンが高く、体重增加も多 かったことから指䐆をくり返す

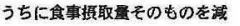
らしてしまった。

図 6 食事量全体が抑制されている症例(A)と食事量全体の多い例(B)

と臨床効果というものが注目された，わが国において も日本透析医学会統計調查委員会より毎年報告)され ている多くの指標とその予後との関連は, 日常診療上 極めて興味深いものである。また，これらの結果を日 常診療に応用していくことが慢性維持透析患者の予後 の改善に㢣がると思われる，当院においては，1997年 1 月より週 3 回透析患者を中心に $\mathrm{TAC}_{\mathrm{BUN}}{ }^{5)}, \mathrm{Kt} / \mathrm{V}^{6)}$,

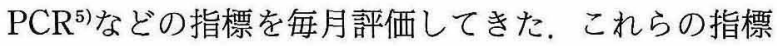

の中には日本透析医学会統計調査委員会で報告されて いる以外のものも含まれている。ここで敢えて Kt/V 以外に $\mathrm{TAC}_{\mathrm{BUN}}$ を算出している理由は, 尿素除去率以 外に臨床上尿素産生率などの影響もより明確にしたい ことと, 保存期および週 1〜2 回の透析期間を含めた血 中 BUN の経時的推移を評価したいためである。とこ ろで, 統計調查委員会送付ソフト算出データと当院で のデータを比較したところ，Kt/V は極めて類似した 


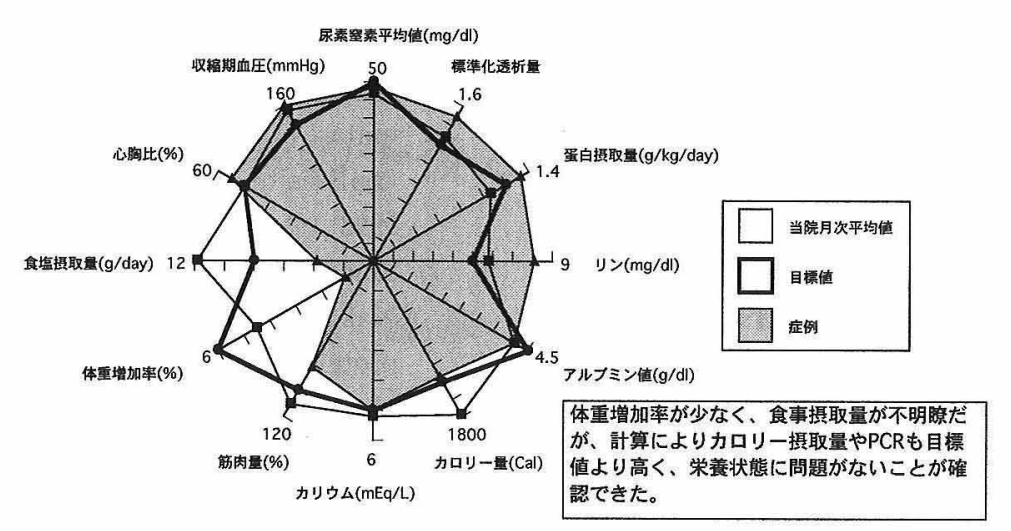

図 7 症例：体重増加率が極めて少なく食事摄取量不足が考えられた症例

結果が得られた $(r=0.996, p<0.0001)$. 一方 PCR に ついては，食塩捸取量やエネルギー捸取量なども算出 する関係から当院では 2 点法 (透析後 $\rightarrow$ 翌透析前採血) を採用しており，それに対し統計調査委員会では，わ が国の現状を踏まえ透析前後の BUN で Kt/V および PCR を求める方法を採用している7). 両者間には幾分 弱いものの相関関係が認められた（ $\mathrm{r}=0.652, \mathrm{p}<$ 0.0001). なお統計調査委員会のような透析前後の BUN を利用し PCR を算出するには高度なプログラ 厶が要求されるのに対し， 2 点法では計算が比較的容 易である。しかし翌透析前の採血を必要とするため日 本の透析施設すべてに適用できる訳ではない．筋肉量 (一部運動量)の指標といわれている\%クレアチニン産 生速度の算出 ${ }^{1)}$ あたっては, 当院では当院算出の PCR を用いているが, 統計調査委員会のデータと比較 した場合これも相関が認められた（r=0.827, $\mathrm{p}<$ 0.0001）。なお，新里3製作の簡便法によるデータと統 計調査委員会ソフトでの算出データとは極めて強い相 関が得られた。エネルギー捸取量については，図 $2 \mathrm{~b}$ の $\mathrm{Y}=\mathrm{X}$ 線上もしくはその近辺に位置する症例 (約 10 例）は目標值と計算值が極めて一致する症例であり， 症例 などのような食事管理に熱心な症例が含ま れている。しかし全体的には目標カロリー值が低い症 例では計算值がより低くなり，逆に目標カロリー值が 高い症例では計算值もより高くなる傾向を示した（回 州係数 0.21).ところでこれらの症例の中には多少尿 量の保持されている症例も含まれていることから計算 カロリー值が過小評価されている症例も含まれてい る。なお，その他の例えばへマトクリット值や鉄， $\beta_{2}-$ マイクログロブリンなどについては月次評価表には敢 えて加えていない.

以上の結果を踏まえ, 個々の症例を診ていく場合, 定期的かつ統一した算定法でその動向を評価していく ことが重要であると認識させられる。また，その表現
法は単純で明快なものでないと患者には理解され難 い. つまり透析データ評価表も数值の羅列だけでは説 得力に欠ける，それに対し，グラフ化は視覚的に訴え ることで説得力を増した。 レーダーグラフであれば多 元的に透析量, 栄養状態, 循環器系指標を表現できる ため効果的であり，患者の評判もまずまずであった。

折れ線グラフであれば単数もしくは複数の指標の動向 を経時的に表現でき, データの悪化改善が一目瞭然で あった. さらにレーダーグラフに扔いては, 他人（当 院平均值で代用）との比較により自分の位置する状況 が理解でき，かつ目標值の設定を行うことが指導をよ り具体的なものとさせた.

ところで，当院で行っている透析評価表およびグラ フの作製は非常に簡単な手技なので，あるいは他の施 設でも日常行われているのかもしれない.ところが, 日常頻繁に使われている方法でありながら，いざ患者 向けに活用しているといった話題は少ないように思わ れる。言い換えれば，今回呈示したような方法は慢性 維持透析患者に対してのインフォームド · コンセント としての役割を十分に担えるのではないだろうか.

\section{結語}

これまで報告されてきた透析指標を参考に当院にお いては 1997 年 1 月から週 3 回慢性維持透析患者を中 心として透析データ評価表を作製してきた。 そのデー 夕の表現法としてグラフ化をはかったところ, 数值羅 列の表形式よりも臨床全体像がとらえ易く, 透析ス タッフおよび慢性維持透析患者において, より病態や 食事管理への理解が深まる結果となった。

\section{文献}

1）日本透析医学会統計調查委員会：わが国の慢性透析療 法の現況（1996 年 12 月 31 日現在）. 透析会誌 $31: 1-$ 
24, 1998

2）木村玄次郎，井上一郎，小嶋俊一，斎藤文雄，河野雄 平, 佐谷 誠, 伊藤敬一, 尾前照雄：透析患者に扛沙 る食事摂取量の定量的算出，腎と透析 $19: 605-610$, 1985

3）新里高弘：Kt/V，及び PCR を算定するための簡便 式. 日本透析医会雑誌 $14 ： 135-136,1998$

4) Gotch FA, Sargent JA : A mechanistic analysis of the National Cooperative Dialysis Study (NCDS). Kidney Int $28: 526-534,1985$

5）木村玄次郎：血液透析に抢ける指標，臨牀透析 10 ：
1631-1639, 1994

6) Daugirdas JT: Second generation logarithmic estimates of single-pool variable volume $\mathrm{Kt} / \mathrm{V}$ : an analysis of error. J Am Soc Nephrol 4: 1205-1213, 1993

7) Shinzato T, Nakai S, Fujita $Y$, Takai I, Morita H, Nakane $\mathrm{K}$, Maeda $\mathrm{K}$ : Determination of $\mathrm{Kt} / \mathrm{V}$ and protein catabolic rate using pre- and postdialysis blood urea nitrogen concentrations. Nephron 67 : 280-290, 1994 